\title{
The Role of Nasyiatul Aisyiyah and Fatayat NU Cadres in Preventing Stunting Cases in Indonesia
}

\author{
Bekti Handayani \\ Master Of Public Health Program, Muhammadiyah University of Jakarta \\ K.H Ahmad Dahlan St, Cirendeu, Ciputat, South Jakarta 15419 \\ E-mail: bekti.handayani2021@gmail.com
}

\begin{abstract}
Stunting is a growth disorder caused by a lack of nutritional intake in toddlers. The factors that cause stunting in developing countries are not giving exclusive breastfeeding, socio-economic constraints, lack of mother's knowledge, and infectious diseases to poor environmental sanitation. The role of Nasyiatul Aisyiyah dan Fatayat NU cadres is needed to eliminate the stunting case in Indonesia. This article is aimed to elaborate on the role of Nasyiatul Aisyiyah and Fatayat NU to decrease stunting cases in Indonesia. This article uses a literature study research method by analyzing the role of Nasyiatul Aisyiyah dan Fatayat NU in Indonesia. In this article, it is stated that Nasyiatul Aisyiyah cadres actively prevent stunting by having the Nutrition House program which is one of the community-based models as an effort to develop food sovereignty and security. Meanwhile, Fatayat $N U$ increases the involvement of community leaders in advocacy, communication, information, and education on family planning, also known as the Proud Kencana program. Thus, the role of Nasyiatul Aisyiyah and Fatayat NU cadres has made a positive contribution in preventing stunting cases in Indonesia.
\end{abstract}

Keywords: Nasyiatul Aisyiyah, Fatayat NU, Stunting 


\section{INTRODUCTION}

Indonesia is still facing various nutritional problems that have a very serious impact on the quality of human resources (HR). One of the nutritional problems that have become a major concern to date is the high number of stunting cases of children under five. In this context, stunting is a condition in which toddlers have a length or height that is less than ideal when compared to their age. This condition is measured by children's length or height that is less than two levels of the children's growth standards from the WHO. Stunting in children under five is a chronic nutritional problem caused by many factors, such as socioeconomic conditions, maternal nutrition during pregnancy, infant pain, and lack of nutritional intake for infants. In addition, stunted children may also experience difficulties in achieving optimal physical and cognitive development in the future (kemkes.go.id, 2018).

It should be noted that, in 2017 , there were $22 \%$ or around 150.8 million children under five in the world experiencing stunting. Furthermore, more than half of the world's stunted children come from Asia (55\%), while a third (39\%) come from Africa. Of the 83.6 million stunted children under five in Asia, the highest proportion is from South Asia (58.7\%) and the lowest proportion is from Central Asia (0.9\%) (Joint Child Malnutrition Estimates, 2018). Meanwhile, Indonesia is the third country with the highest prevalence of stunting in the Southeast Asia region. The average prevalence of stunted children under five in Indonesia in 2005 - 2017 was 36.4\% (WHO, 2018).

In Indonesia, based on the data from the 2018 Basic Health Research (Indonesian: Riset Kesehatan Dasar (RISKESDAS) 2018), the prevalence of malnutrition among children under five in Indonesia is still high, namely, $17.7 \%$ of children under five in Indonesia experienced undernourished (BW/A), 30.8 of them experienced stunting (BL/A or BH/A), and 10.2\% of them experienced underweight $(\mathrm{BW} / \mathrm{BH})$. In addition, the nutritional condition of pregnant women is still of concern, in which $17.3 \%$ of pregnant women are in a condition of chronic energy deficiency and about $50 \%$ of pregnant women suffer from anemia. In pregnant women, the prevalence of chronic energy deficiency, as measured by an upper arm circumference indicator of $<23.5 \mathrm{~cm}$, is $17.3 \%$. Meanwhile, in women of childbearing age who are not pregnant, $14.5 \%$ of them experience chronic energy deficiency (RISKESDAS, 2018). In this case, the condition of the pregnant mother greatly affects the fetus so that it ultimately affects the condition of the baby she is born with (kemkes.go.id, 2019).

In this context, stunting refers to a growth disorder that is mostly caused by nutritional problems. Meanwhile, the definition of stunting according to the WHO is a growth disorder experienced by children due to poor nutrition, repeated infections, and inadequate psychosocial stimuli. Children are considered to experience stunting if their height for age is more than two standard deviations below the WHO's child growth standard. Stunting in early life can be noticed in 
E-ISSN: 2808-5361

http://e-journal.fkmumj.ac.id/
Proceeding The First

Muhammadiyah Internasional-

Public Health and Medicine

Conference

the first 1000 days until the child is two years old. This impaired growth has a functional impact that can be detrimental to children. Stunting is a condition of growth failure in children both in the body and brain. Therefore, it will make children physically grow shorter than normal children in their age and have a delay in thinking. This malnutrition has occurred in the long term from the fetus in the womb to the beginning of the child's life, which is called the first 1000 days of life. Meanwhile, the first 1000 days of life are considered the golden period of a child's life (Indonesia's Ministry of Health, 2019). Furthermore, the factors that cause stunting in children in developing countries are unprovided exclusive breastfeeding, socio-economic conditions, low birth weight, low birth length, low maternal education, and infectious diseases (Budiastuti \& Rahfiludin, 2019; Saadah \& Kp, 2020). Therefore, stunting becomes an urgent issue to be resolved because it has an impact on the quality of Indonesia's human resources in the future. Human resources are the main factors that determine the success of a country.

The impacts caused by stunting can be divided into short-term and long-term impacts (Indonesia's Ministry of Health, 2018). Short-term impacts are as follows. (1) The morbidity and mortality rates increase. (2) Cognitive, motoric, and weight development in children is not optimal. (3) Health costs increase. Meanwhile, the long-term impacts are as follows. (1) Children's posture is not optimal when they are adults, in other words, their body is shorter than normal. (2) Risk of obesity and several other diseases increase, in other words, the impact is that children who suffer from stunting will certainly be more susceptible to disease and, when they have been adults, they are very at risk for degenerative diseases. (3) Reproductive health decreases. (4) Learning capacity and performance are less optimal, especially during the school phase. (5) Productivity and working capacity are not optimal.

Therefore, prevention efforts towards stunting are currently included in the 20205 National Health Focuses. Its target is to reduce the stunting rate to $14 \%$ by 2025 (Indonesia's Ministry of Health, 2019). In overcoming this problem, the Global Strategy for Infant and Young Children Feeding (IYCF) proposes the following steps. The first is to provide the best feeding patterns for infants and children up to 2 years old. The second is to give the baby the Early Breastfeeding Initiation immediately after birth. The third is to provide exclusive breastfeeding. The fourth is to start giving nutritious complementary foods since the baby is 6 months old. The fifth is to continue breastfeeding until the child is 24 months old or more.

This identification shows that the high rate of stunting makes strategic steps highly needed. In other words, achieving the stunting rate reduction target is not only the responsibility of the health sector but also the responsibility of related institutions at all levels of government and the public in general. Without synergy and cooperation to jointly reduce stunting, it is certainly not easy to free Indonesia from stunting. The stunting prevention effort carried out by Indonesia's Ministry of Women 
Empowerment and Child Protection is to develop a stunting prevention model for children under five through the program of 'Kampung Anak Sejahtera'. It is then followed by strengthening the network with forums addressing children's problems as places to accommodate aspirations and pioneers in stunting prevention. This ministry also develops a network with the Family Learning Center (Indonesian: Pusat Pembelajaran Keluarga (PUSPAGA)) (kompas.com, 2021). In other words, the role of cadres of community organizations, such as Muhammadiyah and Nahdlatul Ulama, is highly needed to contribute to reducing stunting rates in Indonesia. This is because both Muhammadiyah and Nahdlatul Ulama are the largest community organizations and have members spread throughout Indonesia. In this article, Muhammadiyah is represented by its women's organization, namely Nasyiatul Aisyiyah, while Nahdlatul Ulama is represented by its women's organization as well, namely Fatayat NU.

Several studies have elaborated on the role of the Muhammadiyah organization in reducing stunting rates in the area of the Sintang Regency, which is still not optimal. This is because there is no special program for Muhammadiyah members to live with proper sanitation, especially in implementing a balanced nutrition pattern and clean \& healthy living behavior (Putra, 2021). Therefore, the difference between this study and the previous ones lies in the active role of the Nasyiatul Aisyiyah and Fatayat NU organizations in suppressing stunting rates in Indonesia. For that reason, this article discusses the question "How is the role of Nasyiatul Aisyiyah and Fatayat NU cadres in suppressing stunting rates in Indonesia?". In terms of the limitation, this study only discusses the contribution of Nasyiatul Aisyiyah and Fatayat NU cadres in suppressing stunting rates in Indonesia.

Nasyiatul Asyiyah that is part of Muhammadiyah needs to invite the central leadership of Muhammadiyah to work together in dealing with the problem of stunting. This is because Muhammadiyah has a large network of cadres accompanied by adequate infrastructure throughout Indonesia. Moreover, Nasyiatul Aisyiyah is known to have initiated a Tough Young Family Movement (Indonesian: Gerakan Keluarga Muda Tangguh), that focuses on 10 pillars. One of them is health and a good environment. This movement aims to provide understanding about stunting to Nasyiatul Aisyiyah members, which is then followed up into a broader stunting understanding movement to the community (nasyiah.or.id, 2016). Furthermore, to date, Nasyiatul Aisyiyah has carried out various ways in socialization efforts and campaigns against stunting prevention, including various approaches with thematic studies and conducting a special meeting in discussing stunting from the point of view of fiqh. In response to this, most of the problems related to stunting are started from the culture and religious understanding possessed by the community. Therefore, it is necessary to build a common understanding, especially academic ones through public education. 
E-ISSN: 2808-5361

http://e-journal.fkmumj.ac.id/
Proceeding The First

Muhammadiyah Internasional-

Public Health and Medicine

Conference

In the event of Tanwir Nasyiatul Aisyiyah in Banjarmasin in November 2017, Nasyiatul Aisyiyah launched 'Gerakan Peduli Stunting' (English: Stunting Care Movement). It is aimed at building the nation's people and generations to be free from stunting because stunting is quite inhibiting the development of the nation. Therefore, it is important to expand the variety of methods and programs. One of them is the community-based program so that stunting prevention can be more effective than only through thematic studies. For example, making a kind of booklet that is easy to read and understand by the public can be included in the work program of this organization. By doing so, written materials can easily be available. Furthermore, it also can be followed by organizing training, counseling, and cooperation with many parties, including with the central leadership of Muhammadiyah.

\section{METHODS}

In this article, the author uses a literature study approach, namely observing and analyzing all information on the research topic. In this approach, there are four steps to be taken, namely as follows. Firstly, the researcher observes and analyzes various information related to the research topic. The information includes the related theories and various previous studies. Secondly, the researcher collects various works of literature relevant to the research topic to explain the phenomena that occur. The collected works of literature for reference are in the form of scientific journals, research papers, and other supporting information. Its purpose is to combine same-theme findings called preliminary studies (Zed, 2008). Therefore, by verifying previous studies, elements of novelty in further research can be found. Thirdly, the researcher identifies various variables that are relevant to the research topic. These variables can provide scope for new research and can also help identify various variables related to the topic research. Lastly, the researcher builds the research framework. In this case, the researcher begins to build the necessary framework by using variables from scientific articles and other related materials. The problem statement in this study becomes the center of the research framework. It aims to be able to answer the research question. As a result, this study may reduce the knowledge gap and provide more relevant information to the research topic.

\section{RESULTS AND DISCUSSION}

Fatayat Nahdlatul Ulama is an Islamic women's organization that is one of the autonomous institutions within the Nahdlatul Ulama organization. It was founded in Surabaya on 24 April 1950 $\mathrm{AD}$, which coincided with 7 Rajab $1369 \mathrm{H}$. To increase and strengthen human resources, this organization holds various forms of leadership cadre training. This cadre training is intended to find candidates for female leaders who will later become leaders of organizations, religions, and nations. All of these activities are carried out at a completely self-supporting cost. When Indonesia entered the New Order (Indonesian: Orde Baru) era under Soeharto's leadership, the space of movement of the Nahdatul Ulama organization and its autonomous bodies, such as Fatayat NU, was controlled and 
E-ISSN: 2808-5361

http://e-journal.fkmumj.ac.id/
Proceeding The First

Muhammadiyah Internasional-

Public Health and Medicine

Conference

limited so they could not be free to move. Fatayat NU must then be able to adapt to government policies. When Mahfudoh Ali Ubaid became the General Chair of PP Fatayat NU from 1979 - 1989, this organization began to support government programs, such as POSYANDU (English: Integrated Health Centers), apotik hidup (English: life pharmacies), and dasa wisma, which were all included in the program of 'Pendidikan Kesejahteraan Keluarga' (PKK) (English: Family Welfare Education) (fatayatnu.or.id, 2020).

In terms of addressing the stunting problem, the role of Fatayat NU is quite significant. Fatayat NU has quite a lot of cadres in Indonesia so that it will certainly be easier to initiate various stunting prevention programs in Indonesia. It should be noted that several steps have been taken by Fatayat NU that are implemented by its cadres. At first, the central leadership of Fatayat NU collaborates with Indonesia's National Population and Family Planning Agency (Indonesian: Badan Kependudukan dan Keluarga Berencana (BKKBN)). The collaboration focuses on increasing cooperation and coordination in strengthening the involvement of community leaders in advocacy, communication, information, and education activities for a family planning program, called 'Bangga Kencana'. This partnership activity is one of the keys to the success of this program, both at the central and regional levels (nu. online, 2021).

In the regional context, Fatayat NU with the support of its cadres is also trying to reduce stunting rates in all regions in Indonesia, as done by Fatayat NU for Bantaeng Branch. This branch of Fatayat NU tries to reduce stunting rates by distributing additional nutritious food for pregnant women and toddlers during the COVID-19 pandemic in Bantaeng, South Sulawesi. This activity takes place on 30 - 31 December 2020. The distributed food is a complementary food for breastfeeding in form of biscuits for toddlers and highly nutritious biscuits for pregnant women. This step is aimed at improving the nutritional status of toddlers and pregnant women in Bantaeng, South Sulawesi. Besides, there are also initiatives from regional administrators that also distribute various packages of additional food assistance for pregnant women and toddlers, as done by Fatayat NU for Sedenreng Rappang Branch, South Sulawesi. The purpose of this movement is to participate in helping the government reduce the number of malnutrition and stunting, by providing the nutritional package for pregnant women and toddlers (bangkitnews. id, 2020). Fatayat NU has taken various steps, including the empowerment program for its cadres at the regional level. This can be traced from the education program for processing Moringa leaves into Moringa juice. This activity is expected to produce an output in the form of alternative food products from Moringa leaves to fulfill the nutrition of pregnant and lactating women in suppressing stunting rates (Ulfah \& Sididi, 2021). Various activities have been held by Fatayat NU to provide knowledge and building awareness of the causes, impacts, and prevention efforts related to stunting. Therefore, the knowledge that has been obtained by Fatayat NU cadres in every piece of training given can be used in daily activities in the family. However, some 
obstacles, such as the economy, environmental sanitation, and the role of the family, still undoubtedly remain a threat for Fatayat NU cadres in helping to reduce stunting in Indonesia.

The establishment of Nasyi'atul Aisyiyah (NA) cannot be separated from the history of Muhammadiyah which is highly concerned about the sustainability of its cadres for the future. The idea of establishing Nasyi'atul Aisyiyah came from Somodirjo, a Muhammadiyah Standard School teacher. Somodirdjo's idea was rolled out in the form of the addition of practical lessons to his students, which was accommodated in joint activities. With the help of Hadjid, the head religion teacher at the Muhammadiyah Standard School in 1919, Somodirdjo succeeded in establishing an association whose members consisted of young male and female students of Muhammadiyah Standard School. The association was named 'Siswa Praja' (SP). The purpose of the establishment of 'Siswa Praja' is to instill a sense of unity, improve students' morals, and deepen religious understanding. Initially, 'Siswa Praja' had branches in Muhammadiyah schools at the time, such as in Suronatan, Karangkajen, Bausasran, and Kotagede. The activity of female members of 'Siswa Praja' was the study of the Quran, speech training, dawn speeches, ringing the alarm (made of bamboo) to wake Muslims to carry out their obligations, namely dawn prayers, holding celebrations of Islamic holidays, and other women's activities. These activities were an innovative breakthrough in the emancipation of women amid the feudal society culture at that time. In 1931, at the 20th Muhammadiyah Congress in Yogyakarta, it was decided that all movement names in Muhammadiyah must use Arabic or Indonesian. With this decision, the name of 'Siswa Paraja Wanita' (or Siswa Paraja for female members) was changed to Nasyiatul Aisyiyah, which is still under the coordination of Aisyiyah (nasyiah.or.id, 2020).

To date, Nasyiatul Aisyiyah plays a significant role in suppressing stunting rates through the MAMPU strategy with the program of 'Rumah Gizi' (English: Nutrition House). Because nutritional problems greatly affect the growth and development of children, it needs government involvement by issuing a policy that embraces various stakeholders, such as higher education institutions, senior high schools, and early childhood education institutions, to become the driving force in fighting stunting. The program of 'Rumah Gizi' from Nasyiatul Aisyiyah aims to improve nutrition and reduce stunting in a community-based manner that has seven activities. This program is certainly intended for Nasyiatul Aisyiyah cadres and Muhammadiyah people in general. It should be noted that this program is one of the community-based models to develop food sovereignty and security. In this program, cross-sectoral coordination is carried out to overcome stunting, such as in the West Sulawesi region (nasyiah.or.id, 2019).

The program of 'Rumah Gizi' developed by Nasyiatul Aisyiyah is a community-based program managed by Balai Sakinah Aisyiyah (BSA), which focuses on women of childbearing age and village cadres. Its purpose is to strengthen the community to overcome the problem of 
E-ISSN: 2808-5361

http://e-journal.fkmumj.ac.id/
Proceeding The First

Muhammadiyah Internasional-

Public Health and Medicine

Conference

malnutrition and stunting. This program is also a family and community-based nutrition program for children who are at risk of protein-energy deficiency in developing countries. This program is in the form of a house which is a place to carry out recovery activities and nutrition education to the community. This program is carried out by identifying the positive behavior of mothers or caregivers who have unnourished children and from poor families. This program does not only refer to the existence of a building but also aims to achieve improved nutritional status, prevent stunting, and develop community-based food sovereignty and security. In this context, there are six activities carried out in this program, nutrition education, nutrition garden management, nutritious local food processing practices, breastfeeding counseling, nutrition counseling, the provision of supplementary food, and sanitation. Nutrition education is related to education about the first 1000 days of life, breastfeeding, and supplementary food other than breast milk (Setyowati \& Rosemary, 2020).

Nasyiatul Aisyiyah also provides education to family members, especially to fathers, because in suppressing stunting rates, the role of father support is highly necessary for exclusive breastfeeding. The role of a father is important because the provision of nutritious food often becomes an obstacle due to the father's smoking behavior. Furthermore, the money spent on smoking can be allocated to meet the nutritional needs of the family. In addition, this program provides breastfeeding counseling for women who have problems with breastfeeding. To support breastfeeding counseling activities, the management of this program holds breastfeeding counseling training for cadres. Breastfeeding counselor training is aimed at health workers (cadres) who have geographic and socio-cultural proximity to the wider community. Furthermore, in the subprogram of the food processing practice, the materials used are local products from nutrition gardens. Another subprogram is nutritional counseling, which involves local health workers and cadres in collaboration with Aisyiyah Muhammadiyah Charity Agency, such as health services (clinics), hospitals, and Muhammadiyah universities.

In carrying out nutrition education, Nasyiatul Aisyiyah conducts food processing training because many people still face challenges in providing quality nutritious food. Nasyiatul Aisyiyah has carried out various stunting prevention efforts which are highly accepted by the community. This is because the approach taken is more participatory and carried out by Nasyiatul Aisyiyah cadres. Therefore, it can be concluded that the program of 'Rumah Gizi' has contributed to the Nasyiatul Aisyiyah cadres to gain valuable lessons in overcoming various stunting problems. In the end, the role of Nasyiatul Aisyiyah cadres in the success of the MAMPU strategy through the program of 'Rumah Gizi' has greatly contributed to improving the health status of the community, including suppressing stunting rates.

\section{CONCLUSION AND SUGGESTIONS}


E-ISSN: 2808-5361

http://e-journal.fkmumj.ac.id/
Proceeding The First

Muhammadiyah Internasional-

Public Health and Medicine

Conference

Stunting prevention must be a common problem because stunting is a multidimensional issue. In other words, stunting prevention must involve all aspects of civil society, both community organizations, and the local community. This is because local communities and community organizations are at the forefront of stunting prevention. In this context, they are Fatayat NU and Nasyiatul Aisyiyah. Fatayat NU has carried out various stunting prevention programs in each region, such as collaborating with various parties to increase cooperation and coordination in increasing the involvement of community leaders in advocacy, communication, information, and education on family planning, which is called 'Bangga Kencana'. In addition, training and counseling programs at the regional level continue to be carried out to improve nutrition for pregnant women and toddlers, which will certainly be able to reduce stunting rates.

Meanwhile, the program initiated by Nasyiatul Aisyiyah in suppressing stunting rates is called 'Rumah Gizi' which aims to increase nutritional status and reduce stunting rates based on community involvement which has seven activities. This program is certainly intended for Nasyiatul Aisyiyah cadres and Muhammadiyah people in general. However, it should be noted that this program is one of the community-based models to develop food sovereignty and security. Furthermore, to carry out nutrition education, Nasyiatul Aisyiyah conducts food processing training because many people still face challenges in providing quality nutritious food. This organization also carries out various community empowerment for increasing knowledge and skills of the community in preventing stunting and malnutrition cases through the program of 'Rumah Gizi'. Therefore, it can be concluded that the tactical steps taken by Fatayat NU and Nasyiatul Aisyiyah have contributed significantly to reducing stunting rates in Indonesia. In the end, the researcher through this article argues that Fatayat NU and Nasyiatul Aisyiyah have contributed positively in efforts to prevent stunting rates in Indonesia.

\section{REFERENCES}

Bangkitnews.id.(2020).https://bangkitnews.id/2020/12/16/fatayat-nu-sidrap menyalurkan-paketbantuan-makanan-tambahan-untuk-ibu-hamil-dan-balita/

Budiastuti, I., \& Rahfiludin, M. Z. (2019). Faktor Risiko Stunting pada anak di Negara Berkembang. Fatayatnu.or.id. (2020). https://fatayatnu.or.id/sejarah/

Kemenkes. (2018). Buletin Jendela Data dan Informasi Kesehatan. Jakarta

Kemenkes. (2019). Pedoman Pelatihan Pelatih Konseling Pemberian Makan Bayi dan Anak (PMBA) Kemkes.go.id. (2018). https://pusdatin.kemkes.go.id/Buletin-Stunting-2018.pdf

Komalasari, K., Supriati, E., Sanjaya, R., \& Ifayanti, H. (2020). Faktor-Faktor Penyebab Kejadian Stunting Pada Balita. Majalah Kesehatan Indonesia, 1(2), 51-56. 
Kompas.com. (2021). https://health.kompas.com/read/2021/03/30/220500468/bukti-sinergi-dankolaborasi-jadi-kunci-atasi-stunting-?page=all

Kontan.co.id. (2019. https://nasional.kontan.co.id/news/stunting-berpotensi-merugikan-negara-iniyang-dilakukan-pemerintah?page=all

Kusumawati, E., Rahardjo, S., \& Sari, H. P. (2015). Model pengendalian faktor risiko stunting pada anak bawah tiga tahun. Kesmas: Jurnal Kesehatan Masyarakat Nasional (National Public Health Journal), 9(3), 249-256.

Mugianti, S., Mulyadi, A., Anam, A. K., \& Najah, Z. L. (2018). Faktor penyebab anak stunting usia 25-60 bulan di Kecamatan Sukorejo kota Blitar. Jurnal Ners dan Kebidanan (Journal of Ners and Midwifery), 5(3), 268-278.

Nu.or.id. (2021). https://www.nu.or.id/post/read/126732/fatayat-nu-sepakati-kerja-sama-cegahstunting-dengan-bkkbn

Nasyiah.or.id. (2016). http://nasyiah.or.id/Welcome/profil/2

Nasyiah.or.id. (2020). http://nasyiah.or.id/Berita/baca/277/Giat-Lakukan-Pencegahan-StuntingNasyiatul-Aisyiyah-Terima-Penghargaan-dari-Pemerintah.html

Pusdatin.Kemkes.go.if. (2020). Downloads/Buletin-Stunting-2018\%20(2).pdf

Pusdatin.kemkes.go.id.(2019).https://pusdatin.kemkes.go.id/resources/download/pusdatin/profilkesehatan-indonesia/Profil-Kesehatan-indonesia-2019.pdf

Promkes.kemkes.go.id. (2014). https://promkes.kemkes.go.id/

Scheffler, C., Hermanussen, M., Bogin, B., Liana, D. S., Taolin, F., Cempaka, P. M. V. P., \& Pulungan, A. (2020). Stunting is not a synonym of malnutrition. European journal of clinical nutrition, 74(3), 377-386.

Setyowati, H. N., \& Rosemary, R. (2020). Rumah Gizi 'Aisyiyah: Komunikasi Kesehatan dengan Pendekatan Agama-Budaya. Jurnal Komunikasi Global, 9(1), 141-161.

Ulfah, N., \& Sididi, M. (2021). Pengolahan Daun Kelor oleh Kelas Ibu Fatayat NU Untuk Pencegahan Stunting di Kab. Takalar. Window of Community Dedication Journal, 57-61.

Yanti, N. D., Betriana, F., \& Kartika, I. R. (2020). Faktor Penyebab Stunting pada Anak: Tinjauan Literatur. REAL in Nursing Journal, 3(1), 1-10.

Wellina, W. F., Kartasurya, M. I., \& Rahfiludin, M. Z. (2016). Faktor risiko stunting pada anak umur 12-24 bulan. Jurnal Gizi Indonesia (The Indonesian Journal of Nutrition), 5(1), 55-61. 